\title{
Urban farming in indoor settings: Nitrate limits compliance check of leafy green vegetables under LED lighting
}

\author{
M. Gräf1 ${ }^{1}$ R. Stangl ${ }^{1}$, R. Hood-Nowotny² and A. Kodym ${ }^{3}$ \\ ${ }^{1}$ University of Natural Resources and Life Sciences, Institute of Soil Bioengineering and Landscape Construction, Vienna, \\ Austria \\ ${ }^{2}$ University of Natural Resources and Life Sciences, Institute of Soil Research, Vienna, Austria \\ ${ }^{3}$ University of Vienna, Department of Pharmacognosy, Vienna, Austria
}

\section{Summary}

In urban farming, the cultivation of leafy vegetables hydroponically under artificial light in indoor settings offers the possibility of decentralized food production. For food safety, the European Commission issued a regulation "EU NO1258/2011" to stipulate the maximum levels for nitrate in food. We conducted this study to determine, whether leafy vegetables grown in indoor settings can comply these nitrate limits. The air temperature, relative humidity and light intensities for all treatments were maintained at $23 \pm 2^{\circ} \mathrm{C}$, $45 \pm 10 \%$ and $120 \pm 10 \mu \mathrm{mol} \mathrm{m} \mathrm{m}^{-2} \mathrm{~s}^{-1}$ at a photoperiod of 16 hours, with two different light spectra: red-blue (RB) vs. red-green-blue (RGB). Fresh food biomass, nitrate, nitrogen and SPAD readings of three different leafy vegetables (cabbage, pak choi, and rocket) were analyzed. The nitrate limits were met by all species, but are high compared to plants traditionally soil cultivated. Furthermore, a significantly reduced nitrate accumulation was found for the species rocket under the RGB treatment compared to the RB. This study proposes the integration of green light to red and blue in urban indoor farming, as a strategy to reduce the nitrate content of selected vegetables and to improve food quality and make it consumer-friendly.

\section{Keywords}

artificial light, hydroponic, indoor farming, nitrate accumulation, soil-less

\section{Introduction}

According to the United Nations (2017) the global human population is growing by $1.1 \%$ per year, expected to swell to over 8.6 billion by 2030 . In 2018, 55\% of the world's inhabitants were living in urban areas and by 2050 , the number of urban inhabitants is expected to increase by $68 \%$ (United Nations, 2018). To face the challenges of this urbanite increase, cities need to be self-regulating and sustainable systems (Deelstra and Girardet, 2000). Urban farming as a form of decentralised food production can make valuable contributions towards this goal. An entirely new field has emerged; cultivating vegetables hydroponically under artificial light has become very popular with city dwellers looking for healthy and local products. This technology, which was initially investigated by NASA in the early 1980s to produce food for space missions, is now readily available to the public (Kliss et al., 2000). Mainly due to the development of LEDs, these systems have become increasingly cost- and ener-

\section{Significance of this study}

What is already known on this subject?

- Nitrate values in leafy vegetables are subject to large fluctuations. Nitrogenous fertilisers and light conditions are the two main factors driving those, both factors which can be regulated under controlled environment.

\section{What are the new findings?}

- The nitrate content of the species rocket, cabbage and pak choi was within the limits set by the European Commission, which were cultivated hydroponically in a household setting under artificial light. Moreover, lower nitrate accumulation was found for all species under the RGB-LED compared to the RB-LED, but significantly only in rocket.

\section{What is the expected impact on horticulture?}

- In addition to red and blue light, the wavelength range between 500-600 nm should be considered when designing LEDs for the cultivation of leafy vegetables.

gy-efficient (Morrow, 2008; Mitchell et al., 2012; Darko et al., 2014). Professional closed plant production systems, socalled plant factories, increasingly produce leafy vegetables with minimal use of light, energy, water, $\mathrm{CO}_{2}$ and inorganic fertilizers (Kozai, 2013). Manufacturers such as Ikea and resellers like Amazon have launched a variety of products, in which suspended net-pots are placed in a nutrient solution in non-circulating hydroponic systems. These systems are easy to use and intended for non-professional end customers. The nutrient management in hydroponic systems is an important factor for controlling plant growth. Nutrient solutions are based on high nitrogen, phosphate and potassium uptake. Nitrogen $(\mathrm{N})$ is an important macronutrient that plays a key role in the growth and development of plants (Scheible et al., 2004; Yuan et al., 2012). The main form of $\mathrm{N}$ uptake in plants is inorganic specific in the form of nitrate, which is indispensable for the biosynthesis of proteins and nucleic acids (Durazzo et al., 2013). After absorption, nitrate is either stored in the vacuole or reduced to nitrite by nitrate reductase (NR). Nitrite enters the chloroplast and is then reduced to ammonia by nitrite reductase (NiR) (Crawford, 1995). The reduction of nitrate to ammonium and its integration into organic molecules is called nitrogen assimilation. The formation of nitrate reductase is induced by the availability of nitrate and light, whereby phytochrome is the photoreceptor 
(Bian et al., 2018). When the absorption of nitrate exceeds its assimilation, nitrate will accumulate in plants (Imsande and Touraine, 1994). This can lead to high absorption of nitrate in vegetable leaves (Di Lorenzo et al., 2013; Sago and Shigemura, 2018). Metabolites and reaction products of nitrate, such as nitrite, nitric oxide and $\mathrm{N}$-nitroso compounds can lead to effects such as methaemoglobinaemia and carcinogenesis, if consumed excessively (Gangolli et al., 1994; Santamaria, 2006; Anjana and Iqbal, 2007; Keszei et al., 2013; Dellavalle et al., 2013; Brkić et al., 2017). Human nitrate pollution is mainly exogenous through the consumption of vegetables (European Food Safety Authority, 2008). Therefore, the European Commission (2011) issued a regulation "EU NO1258/2011" to stipulate the maximum levels for nitrate in food. Compliance with legal limits is essential for food safety, especially for leafy vegetables, which can accumulate high nitrate levels (Gorenjak and Cencič, 2013; Bian et al., 2016; Fu et al., 2017). Nitrogenous fertilisers and light conditions are the two major factors that influence plant nitrate levels (Wanlai et al., 2013; Bian et al., 2015; Fu et al., 2017). A previous study with lettuce has shown that the nitrate content of leaves increases significantly when plants are exposed to suboptimal light intensity and excessive nitrogen fertilisation, leading to an imbalance in absorption between uptake and reduction of nitrate ions, resulting in higher nitrate accumulation (Khan et al., 2018). Light conditions can be subdivided into light quality and intensity; both play a key role in nitrate accumulation (Lillo and Appenroth, 2001). Light quality refers to the wavelength emitted by the light source; it is well known that red (R) and blue (B) lights combined have the greatest impact on plant growth (Olle and Viršile, 2013; Loconsole et al., 2019). The light intensity in horticulture is defined as the number of photons per time and area $\left(\mu \mathrm{mol} \mathrm{m} \mathrm{m}^{-2} \mathrm{~s}^{-1}\right)$ in the spectral range of 400-700 nm, which is called the photosynthetic active radiation (PAR), that strikes the plant (Xu, 2019). Green light (500-600 nm) had been thought to provide an near-ineffective range of wavelengths for the growth, development and photosynthesis in plants, due to it having higher reflectiveness and a lower absorption rate than red and blue light (Folta and Maruhnich, 2007; Johkan et al., 2012). However, there are studies showing effects of green light, for example that additional green light in the pre-harvest phase improves the quality of crisp head lettuce (ascorbic acid content and shoot biomass) (Saengtharatip et al., 2020). Most of the available LED light systems in vegetable cultivation combine only red and blue LEDs, but little is known of the combined effect of green, red and blue LEDs (Liu et al., 2016). However, there is a research gap to support the role of green light as an essential light source for plant growth and development; we therefore conducted this experiment, to test different spectral distributions on a range of commonly home grown plants. Since the plants in these indoor farming systems are cultivated with artificial light, it is important to verify whether they can comply with the prescribed nitrate limit values. Therefore, we have reproduced a setup used by non-professional users to achieve realistic results.

The European Commission (2011) has set the maximum nitrate concentration for rocket (Eruca ssp. and Diplotaxis spp.) higher than for other species, e.g., lettuce or spinach. Among leafy vegetables, rocket is considered to be an hyper-accumulator of nitrate, so in this study the species rocket (Eruca vesicaria ssp. sativa) was used for cultivation in addition to cabbage (Brassica oleracea var. capitata f. alba) and pak choi (Brassica rapa L. ssp. chinensis) (Bianco et al., 1998; Cavaiuolo and Ferrante, 2014; Bell and Wagstaff, 2019). To determine whether the nitrate contents were within the limits set by the European Commission, we used a new simple method for measuring plant nitrate concentrations. We put forward the hypothesis that leafy vegetables such as rocket, cabbage and pak choi, grown hydroponically under artificial light in a non-professional system, exceed the nitrate limits set by the European Commission. In addition to the nitrate content of the leaf mass, we also assessed the fresh weight, the nitrogen content, and the SPAD values of these three leafy vegetables, which were grown under two LEDs, red-blue (RB) and red-green-blue (RGB) at the same light intensity in a non-circulating hydroponic system.

\section{Material and methods}

\section{Experimental design and growth conditions}

Seeds of pak choi (Brassica rapa L. ssp. chinensis), cabbage (Brassica oleracea var. capitata f. alba) and rocket (Eruca vesicaria ssp. sativa) were sown onto rock wool pads and put into the germination container (Article number 203.187.24, IKEA, Leiden, Netherlands). Ten days after sowing, the seedlings with one set of fully expanded leaves were transferred to square net pots with a side length of $70 \mathrm{~mm}$ filled with pumice and placed randomly into growth containers (103.187.29, IKEA) (Figure 1). Then water and a hydroponic solution (203.176.49, IKEA) with the nutrient formula 5-3-8 (N-P-K) and a pH of 5.5-6.5, which contained the following nutrients as shown in Table 1 was added. The water level was kept between the minimum and maximum marks on the container according to the manufacturer's instructions by regularly refilling $1.5 \mathrm{~L}$ per week and tray ( $4 \mathrm{~mL}$ of the nutrient solution per $1 \mathrm{~L}$ of water); this was generally similar across treatments. The $\mathrm{pH}$ of the nutrient solution was monitored prior to each fertilization event and ranged between 6.1 and 7.1. Given the similar $\mathrm{pH}$ values across treatments, the near neutral status of the solution and in an attempt to follow "home-grower" practice, $\mathrm{pH}$ adjustment was not carried out.

Ten biological replicates were cultivated per light source and species, with three different species and two different light sources resulting in a total sample size of 60 (Figure 2). Those were cultured for a period of six weeks after transplantation. Two different LED modules, Växer-RGB (903.231.09, IKEA) and Aenano-RB (Wabe, Vienna, Austria) supplied artificial light. Light intensity was measured with a quantum sensor LI-190R (LICOR, Lincoln, USA) to position

TABLE 1. Contents of the nutrient solution per irrigation process per liter.

\begin{tabular}{lcc}
\hline Nutritive material & $\begin{array}{c}\text { Pro fertilization run } \\
\left(\mathrm{mmol} \mathrm{L}^{-1}\right)\end{array}$ & $\begin{array}{c}\text { Pro fertilization run } \\
\left(\mathrm{mg} \mathrm{L}^{-1}\right)\end{array}$ \\
\hline Total nitrogen (N) & 14.278 & 200 \\
Nitrate nitrogen & 9.995 & 140 \\
Ammonium nitrogen & 4.283 & 60 \\
Phosphorus (P) & 0.325 & 120 \\
Potassium (K) & 2.820 & 320 \\
\hline & $\mu \mathrm{mol} \mathrm{L}^{-1}$ & \\
\hline Boron (B) & 36.999 & 0.4 \\
Copper (Cu) & 1.258 & 0.08 \\
Iron (Fe) & 35.813 & 2 \\
Manganese (Mn) & 7.280 & 0.4 \\
Molybdenum (Mo) & 0.416 & 0.04 \\
Zink (Zn) & 1.835 & 0.12 \\
\hline
\end{tabular}




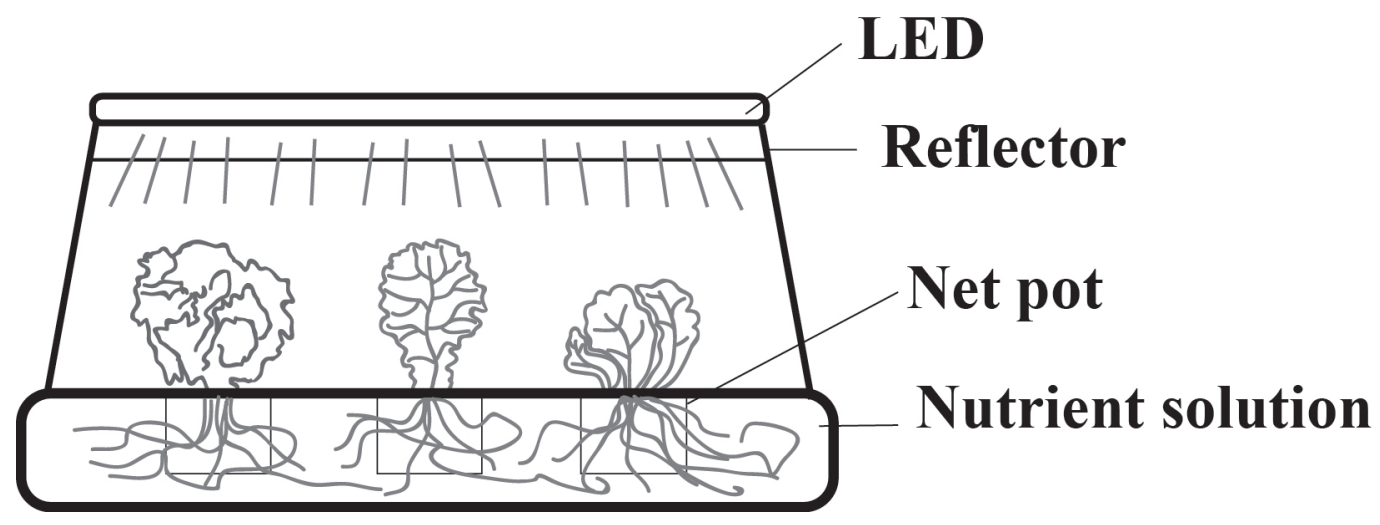

FIGURE 1. Schematic section of the tray in which the plants were cultivated.

the two lamps above the plants to provide the same light intensity. Subsequently, light spectra were measured with a spectroradiometer ILT 550 (International Light Technologies, Peabody, USA). Peak wavelengths of both lamps of red and blue were $450 \mathrm{~nm}$ and $660 \mathrm{~nm}$. In addition, the RGB-LED emitted at 490-570 nm and the RB-LED at $410 \mathrm{~nm}$, which distinguished the two lamps (Figure 3). The RGB-LED emitted 40,25 and $35 \%$ of red, green, and blue, and the RB-LED 65 and $35 \%$ red and blue, respectively. Air temperature, relative humidity and light intensities for all treatments were maintained at $23 \pm 2{ }^{\circ} \mathrm{C}, 45 \pm 10 \%$ and $120 \pm 10 \mu \mathrm{mol} \mathrm{m}^{-2} \mathrm{~s}^{-1}$ at a photoperiod of $16 \mathrm{~h}$.

\section{Measurements of plant biomass and SPAD}

Six weeks after transplantation, all plant organs above ground level were harvested and the fresh biomass of the leaves was measured. To measure chlorophyll concentrations, the portable chlorophyll meter SPAD-502 (Konica Minolta Sensing, Osaka, Japan) was used, measuring on the third fully developed leaf from the top from each plant. For each leaf, five measurements were taken and averaged (Uddling et al., 2007).

\section{Determination of nitrate}

At the time of harvest, from each plant (in total 60), two samples were taken, measured and averaged. By using a standard office hole puncher, a $5.5 \mathrm{~mm}$ diameter sample was punched out from the same leaf from which the chlorophyll measurements had been taken, and was weighed on a five-figure balance. Nitrate content in leaves was determined

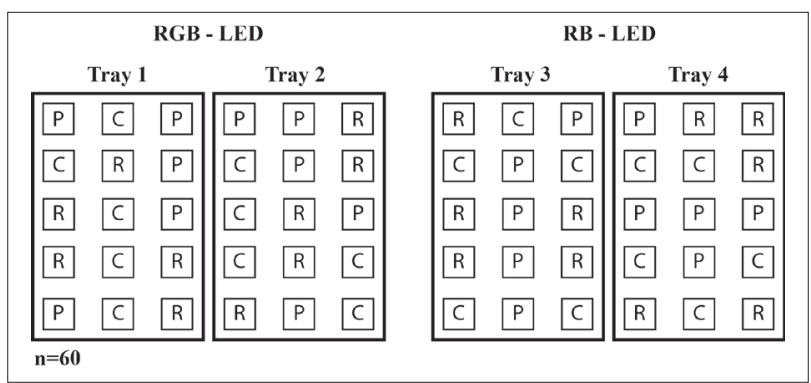

FIGURE 2. Illustration of the experimental setup, ten replicates per plant species for each light treatment (RGB and RB) were placed randomly in the plant trays $(n=60), \mathrm{P}=$ pak choi, $\mathrm{C}=$ cabbage, $\mathrm{R}=$ rocket. based on an adaptation of the spectrophotometric method described by Miranda (2001). A single leaf disc sample was placed in a 2-mL microcentrifuge tube (Eppendorf), filled with $1 \mathrm{~mL}$ of distilled water, and then frozen at $-80^{\circ} \mathrm{C}$. To the frozen samples, two stainless steel balls were added and homogenised for five minutes with an oscillating mill (Retsch, Haan, DE) running with a frequency of 20 oscillations per second. The samples were further diluted with $1 \mathrm{~mL}$ of distilled water and vortexed. Nitrate concentration of the prepared solution was determined, based on a colorimetric reaction where nitrate is converted into nitrite $\left(\mathrm{NO}_{2}{ }^{-}\right)$in an acidic vanadium chloride $\left(\mathrm{VCl}_{3}\right)$ medium. $\mathrm{NO}_{2}^{-}$concentration was then measured by direct coupling with the Griess reaction. Absorbance was measured at $540 \mathrm{~nm}$ on a micro-titre plate spectrophotometer (Hood-Nowotny et al., 2010; Miranda et al., 2001). Fifty $\mathrm{mL}$ of vanadium (III) chloride solution $\left(8 \mathrm{~g} \mathrm{~L}^{-1}\right.$ $\mathrm{VCL}_{3} 97 \%$ in $\left.1 \mathrm{M} \mathrm{HCl}\right), 100 \mathrm{~mL}$ of Griess reagent I $\left(=200 \mathrm{mg} \mathrm{L}^{-1}\right.$ $\mathrm{N}$-naphthylethylenediamine dihydrochloride) and $100 \mathrm{~mL}$ of Griess reagent II (10 $\mathrm{g} \mathrm{L}^{-1}$ sulphanilamide in $\left.3 \mathrm{M} \mathrm{HCl}\right)$ were prepared (Molecular Probes, 2003). Subsequently, $100 \mu \mathrm{L}$ of the homogenised sample with $100 \mu \mathrm{L}$ of $\mathrm{VCl}_{3}, 50 \mu \mathrm{L}$ of Griess I and $50 \mu \mathrm{L}$ of Griess II were mixed and incubated for 60 minutes at $37^{\circ} \mathrm{C}$. A full set of blanks and standards were run concurrently. Nitrate standards ranging from 1-10 $\mu \mathrm{g}$

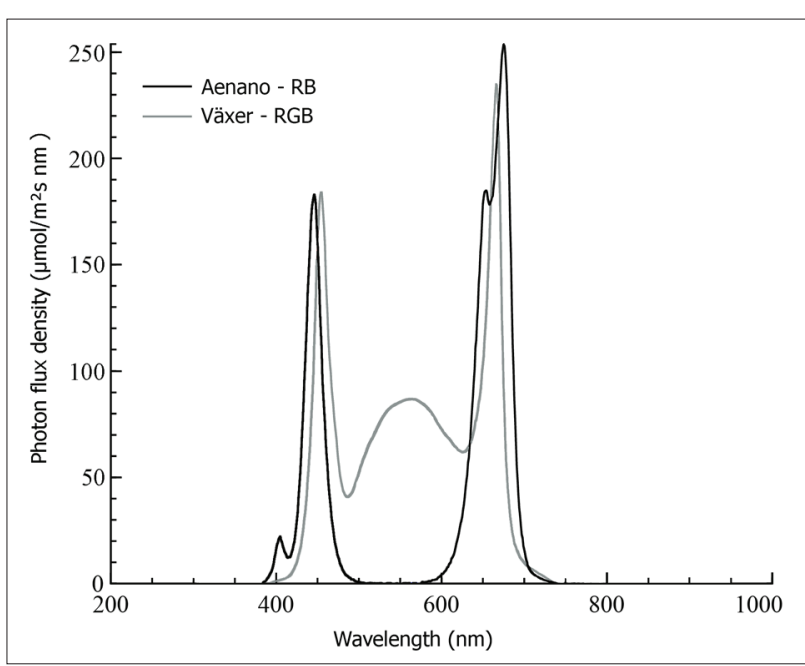

FIGURE 3. Spectrum of the RGB-LED and the RB-LED projected one above the other, with a spectroradiometer ILT 550 from International Light Technologies. 
TABLE 2. Fresh weight, SPAD value, nitrate content and $\% \mathrm{~N}$ of the three tested species in a non-circulating hydroponic system under two different light treatments. Table shows means \pm SE, separation with letters by Tukey HSD test at $\mathrm{P}<0.05$.

\begin{tabular}{lcccccccc}
\hline \multirow{2}{*}{$\begin{array}{l}\text { Crop plant } \\
(n=10)\end{array}$} & \multicolumn{2}{c}{ Fresh weight $(\mathrm{g})$} & \multicolumn{2}{c}{ SPAD } & \multicolumn{2}{c}{ Nitrate $\left(\mathrm{mg} \mathrm{NO}_{3} \mathrm{~kg}^{-1}\right)$} & & $\% \mathrm{~N}$ \\
\cline { 2 - 9 } & RGB & RB & RGB & RB & RGB & RB & RGB & RB \\
\hline Cabbage & $22.6^{\mathrm{a}} \pm 3.7$ & $23.8^{\mathrm{a}} \pm 3.0$ & $49.7^{\mathrm{a}} \pm 2.8$ & $45.8^{\mathrm{a}} \pm 2.2$ & $2.645^{\mathrm{a}} \pm 122$ & $2.856^{\mathrm{a}} \pm 128$ & $6.37^{\mathrm{a}} \pm 1.1$ & $7.45^{\mathrm{a}} \pm 1.3$ \\
Pak choi & $10.8^{\mathrm{b}} \pm 1.9$ & $12.7^{\mathrm{b}} \pm 2.5$ & $50.6^{\mathrm{ab}} \pm 1.3$ & $56.6^{\mathrm{b}} \pm 3.0$ & $2.351^{\mathrm{a}} \pm 255$ & $2.585^{\mathrm{a}} \pm 158$ & $7.09^{\mathrm{a}} \pm 1.4$ & $7.27^{\mathrm{a}} \pm 1.3$ \\
Rocket & $12.0^{\mathrm{b}} \pm 1.5$ & $13.4^{\mathrm{b}} \pm 1.8$ & $30.7^{\mathrm{c}} \pm 1.6$ & $41.5^{\mathrm{d}} \pm 1.4$ & $2.505^{\mathrm{a}} \pm 343$ & $3.449^{\mathrm{b}} \pm 181$ & $8.03^{\mathrm{a}} \pm 1.5$ & $7.56^{\mathrm{a}} \pm 1.8$ \\
\hline
\end{tabular}

$\mathrm{N} \mathrm{mL}^{-1}$ were prepared by serial dilution with distilled water of a commercially available stock standard (Sigma Aldrich). The absorbance of the samples and standards was measured on an EnSpire 2300 multilabel plate reader. The absorbance of distilled water (blank) was subtracted from all measurements. Nitrate concentration was determined by plotting the absorption values against values of a known standard series. Standard plots were only accepted when $r^{2}$ was $>0.98$, but were typically 0.999 . Sample dilutions were carried out to ensure, that the samples were within the bracketed range of the standards. All dilutions were accounted for and concentrations calculated back to the fresh weight of the punched sample and multiplied by the factor 1,000 to obtain values in $\mathrm{mg} \mathrm{NO}_{3}{ }^{-} \mathrm{kg}^{-1}$ (= ppm).

\section{Nitrogen analysis}

For nitrogen analysis, dried plant samples $\left(60^{\circ} \mathrm{C}\right.$ for $\left.48 \mathrm{~h}\right)$ were finely ground with an oscillating mill MM 301 (Retsch) and accurately weighed (3-5 mg) into 5-mm tin cups. Samples were analysed using a Thermo Flash 2000 Organic Elemental analyser. A full set of internal and external standards was run with the samples to calculate $\% \mathrm{~N}$ values.

\section{Statistical analysis}

Data were analysed with the Software R Studio (Version 1.1.463, R Studio, Boston, USA) using $5 \%$ as the level of significance. The Shapiro-Wilk test was performed to verify normal distribution and the Levene test was applied to proof homogeneity of variances. Then, a multifactorial analysis of variance followed by a Tukey HSD test was subjected. For the relationship between SPAD and nitrate concentration a standard regression analysis was carried out.

\section{Results}

\section{Plant biomass and SPAD}

For plant biomass the two-way ANOVA analysis revealed that there was no significant difference between the light treatments, but cabbage differed significantly from pak choi and rocket (Table 2). The average fresh weight (FW) per plant in the RGB light treatment was $15.1 \mathrm{~g}$ and $16.6 \mathrm{~g}$ under the RB-LED. The total fresh weight yield per tray with a surface

TABLE 3. Maximum measured nitrate values and the corresponding legal limit values from the European Commission (2011).

\begin{tabular}{lccc}
\hline \multirow{2}{*}{$\begin{array}{l}\text { Crop plant } \\
n=10\end{array}$} & \multicolumn{2}{c}{$\begin{array}{c}\text { Maximum values measured } \\
\left(\mathrm{mg} \mathrm{NO}_{3} \mathrm{~kg}^{-1}\right)\end{array}$} & \multirow{2}{*}{$\begin{array}{c}\text { Limit values } \\
\left(\mathrm{mg} \mathrm{NO}_{3} \mathrm{~kg}^{-1}\right)\end{array}$} \\
\cline { 2 - 3 } & $\mathrm{RGB}$ & $\mathrm{RB}$ & \\
\hline Cabbage & 3,071 & 3,084 & 4,000 \\
Pak choi & 2,350 & 3,316 & 4,000 \\
Rocket & 3,891 & 3,949 & 6,000 \\
\hline
\end{tabular}

of $0.165 \mathrm{~m}^{2}$ amounted to an average harvest of $227 \mathrm{~g}$ for the plants under the RGB-LED and $249 \mathrm{~g}$ in the RB treatments, with each tray containing 15 plants. This equals a total yield of approximately $1.4 \mathrm{t} \mathrm{ha}^{-1}$. Highest yields were reached by cabbage with around 23 g per plant (Table 2). SPAD readings were significantly different between the species, but not between the light treatments, except for rocket. The SPAD value of rocket under the RGB-LED was significantly lower with mean values of 30.7 than under the RB-LED (41.5) at a p-value of 0.009 . The statistical model exposed an interaction between light and species, which means that the effect of light was different depending on the species. Regression analysis showed no linear correlation between the SPAD value and the nitrate concentration for any species, although there was a significant correlation between SPAD and bulk \% $\mathrm{N}$ of the plant material, however predictive power of the SPAD reading was low $\left(\mathrm{R}^{2}<0.5\right)$.

\section{Nitrate and nitrogen}

We observed slightly higher nitrate levels in all plants under the RB than in the RGB-LED with differences of $234 \mathrm{mg}$ $\mathrm{NO}_{3}{ }^{-} \mathrm{kg}^{-1}$ in pak choi, $211 \mathrm{mg} \mathrm{NO}_{3}{ }^{-} \mathrm{kg}^{-1}$ in cabbage and $944 \mathrm{mg}$ $\mathrm{NO}_{3}{ }^{-} \mathrm{kg}^{-1}$ in rocket. The two-way ANOVA showed a significant influence of the light on the nitrate content, but not between the species. Nitrate content of rocket grown under the RBLED was significantly higher than under the RGB-LED, with highest value of $3,949 \mathrm{mg} \mathrm{NO}_{3}^{-} \mathrm{kg}^{-1}$. Therefore the average amount of nitrate in the plants grown under the RGB-LED was significantly lower at $2,500 \mathrm{mg} \mathrm{NO}{ }_{3}^{-} \mathrm{kg}^{-1}$ compared to $2,963 \mathrm{mg} \mathrm{NO}_{3}{ }^{-} \mathrm{kg}^{-1}$ in the plants under the RB-LED (Table 2). Bulk percentage $\mathrm{N}$ was not different between light sources or between species. As shown in Table 3, the nitrate levels of all plant species were found to be within the range set by the European Commission. Nitrate values of cabbage and pak choi were within the limit values of $4,000 \mathrm{mg} \mathrm{NO}_{3}^{-} \mathrm{kg}^{-1}$, nitrate levels of rocket were within the range of $6,000 \mathrm{mg}$ $\mathrm{NO}_{3}{ }^{-} \mathrm{kg}^{-1}$.

\section{Discussion}

There was no significant influence of the different light treatments on the fresh weight of the plants, only differences between the species. Although Johkan et al. (2012) and Kim et al. $(2004 \mathrm{a}, \mathrm{b})$, reported that green light (500-600 $\mathrm{nm})$ in addition to red and blue LEDs enhance plant growth, this was not supported by our results. Nevertheless, all plants complied with the nitrate limits set by the European Commission. Guadagnin (2005) examined rocket plants that were cultivated organically, conventionally and hydroponically and found mean values of 4,073, 5,377 and 8,243 $\mathrm{mg} \mathrm{NO}_{3}^{-} \mathrm{kg}^{-1}$. Generally, nitrate values are subject to large fluctuations due to different growing conditions, a factor which is eliminated under a controlled environment (European Food Safety Authority, 2008). Nitrate concentrations in leafy vegetables tend to be higher in hydroponic systems than those under conventional cultivation (in the ground with sunlight) (Gua- 
dagnin et al., 2005; Chen et al., 2014; Yosoff et al., 2015; Oka et al., 2016). Kmecl (2017) tested cabbage grown outdoors in the field with soil and found average nitrate values of $795 \mathrm{mg}$ $\mathrm{NO}_{3}^{-} \mathrm{kg}^{-1}$ with maximum values of $1,964 \mathrm{mg} \mathrm{NO}_{3}^{-} \mathrm{kg}^{-1}$. This is largely consistent with our results and also shows similar fluctuations in the nitrate levels of the plants.

The Joint Expert Committee of Food and Agriculture (JECFA) Organization of the World Health Organization defined an acceptable daily intake (ADI) for nitrate of $3.7 \mathrm{mg} \mathrm{kg}^{-1}$ body weight per day. This is equivalent to an intake of $259 \mathrm{mg}$ nitrate per day for a 70-kg adult (World Health Organization, 2004). In accordance with the WHO (2004) health targets a consumption of $400 \mathrm{~g}$ day $^{-1}$ of fruit or vegetables is recommended. Consuming $100 \mathrm{~g}$ of raw leafy vegetables grown under the current conditions with a mean nitrate concentration of 2,700 $\mathrm{mg} \mathrm{NO}_{3}{ }^{-} \mathrm{kg}^{-1}$ would lead to a daily intake of $270 \mathrm{mg} \mathrm{NO}_{3}$; which would slightly exceed the defined ADI (Santamaria, 2006). However, health targets should be possible to achieve without exceeding thresholds, by consuming a mixed diet. Moreover, measures could be taken to reduce the nitrate content in the run-up to the harvest, e.g., continuous lighting of the plants before harvesting and an adequate, but not excessive supply of nutrients for optimum yield (Bian et al., 2016; Chowdhury and Das, 2015). As well as the use of optimal spectral distributions, to ensure maximum yield and low nitrate levels in the plant biomass. The distribution of the light quality and its effects on nitrate uptake and accumulation is far from being fully elucidated (Bian et al., 2015; Colla et al., 2018).

Rocket cultivated under the RGB treatment showed significantly lower nitrate values compared to the RB with the same light intensities. Lin et al. (2013) found that nitrate accumulation in lettuce plants was lower under RB with additional 500-600 $\mathrm{nm}$ wide spectral energy than under RB alone, which underpins our findings. The expression of the genes for biosynthesis of $\mathrm{NO}_{3}{ }^{-}$and $\mathrm{NO}_{2}^{-}$reductase (NR and $\mathrm{NiR}$, respectively) in leaves is regulated by the phytochrome system at absorbance levels at 665 and $735 \mathrm{~nm}$ (Lillo and Appenroth, 2001). Bian et al. (2018) reported, that adding green light to red and blue light had positive effects on the activity and expression of nitrate assimilation related genes NR and NiR. Similar results were obtained by Liu et al. (2016), cold white fluorescent light (T5) and broad spectrum high pressure sodium lamps (HPS) reduced the nitrate content in lettuce by $62 \%$ compared to the mixture of RB-LED light. They believe that a broad spectral composition stimulates nitrate assimilation by contributing to protein synthesis and thus reducing nitrate accumulation in lettuce plants (Liu et al., 2016). This hypothesis is in line with a recent study which indicates that the variability of nitrate enrichment is not only due to differences in absorption, but also in the efficiency of its chemical reduction (Colla et al., 2018). Surprisingly, no differences were found in the bulk percentage nitrogen in the leaf mass between the different light treatments. This preliminary finding suggests that the plants have absorbed another form of nitrogen in addition to nitrate from the nutrient solution, namely ammonium, as otherwise there would also have to be a visible nitrogen difference in the leaf mass. One way to monitor the nutritional status of the plant non-destructively is to use a chlorophyll meter. Therefore, a model is required for the selected species that describes the relationship between SPAD and the foliar nitrogen status (Fox and Walthall, 2008; Souza et al., 2019). SPAD readings and leaf nitrogen content lack a direct relationship which may be related to the nitrogen distribution between photosynthetic proteins (Makino and Osmond, 1991; Xiong et al., 2015). The pattern of leaf nitrogen allocation between soluble proteins, photosynthetic enzymes and the reaction center complexes of thylakoids varies with supply of nitrogen and light conditions (Mu et al., 2016). Snowden et al. (2016) found decreased chlorophyll concentrations with additional green light in tomato, cucumber, pepper and lettuce. We observed the same for the species rocket under the RGB treatment. A possible explanation for this might be that plants with restricted growth or a more compact form have a chlorophyll concentration, but to prove this, leaf area data is required (Fan et al., 2013). Further research should be undertaken to investigate the activity of the enzyme related to $\mathrm{NR}$ and NiR and the absorption of chemical nitrogen forms from the nutrient solution, as well as the relationships with the leaf chlorophyll content.

\section{Conclusions}

- The tested species pak choi, cabbage, and rocket, grown in a non-circulating hydroponic household system, meet the nitrate limits set by the European Commission, regardless of light treatment.

- A significantly lower nitrate concentration was found in the species rocket under the RGB-LED compared to the RB-LED.

- We therefore recommend additional green light to red and blue when growing leafy greens in a non-professional environment with artificial light.

\section{Acknowledgments}

Thanks to G. Bachmann for the light measurements and fruitful discussions and to S. Stückler for technical support.

\section{Funding}

This work was funded by an Innovationsscheck Plus grant of the Austrian Research Promotion Agency (FFG).

\section{Author contributions statement}

AK initiated the project. AK, MG and RH conceived and designed the analysis. MG and AK carried out the experiment. RS helped supervise the project. MG collected the data. AK and RH contributed analysis tools. MG performed analysis, drafted the manuscript and designed the figures. MG, AK, $\mathrm{RH}$ and RS contributed to the writing of the manuscript.

All authors discussed the results and contributed to the final manuscript.

\section{Conflict of interest statement}

All authors declare no conflict of interest in the submitted work.

\section{References}

Anjana, S.U., and Iqbal, M. (2007). Nitrate accumulation in plants, factors affecting the process, and human health implications. A review. Agron. Sustain. Dev. 27(1), 45-57. https://doi. org/10.1051/agro:2006021.

Bell, L., and Wagstaff, C. (2019). Rocket science: A review of phytochemical \& health-related research in Eruca \& Diplotaxis species. Food chem. X1, 100002. https://doi.org/10.1016/j. fochx.2018.100002.

Bian, Z.H., Yang, Q.C., and Liu, W.K. (2015). Effects of light quality on the accumulation of phytochemicals in vegetables produced in controlled environments: A review. J. Sci. Food Agric. 95(5), 869877. https://doi.org/10.1002/jsfa.6789. 
Bian, Z.H., Cheng, R., Yang, Q.C., Wang, J., and Lu, C. (2016). Continuous light from red, blue, and green light-emitting diodes reduces nitrate content and enhances phytochemical concentrations and antioxidant capacity in lettuce. J. Am. Soc. Hortic. Sci. 141(2), 186-195. https:// doi.org/10.21273/JASHS.141.2.186.

Bian, Z.H., Cheng, R., Wang, Y., Yang, Q.C., and Lu, C. (2018). Effect of green light on nitrate reduction and edible quality of hydroponically grown lettuce (Lactuca sativa L.) under short-term continuous light from red and blue light-emitting diodes. Environm. Experim. Bot. 153, 63-71. https://doi.org/10.1016/j.envexpbot.2018.05.010.

Bianco, V.V., Santamaria, P., and Elia, A. (1998). Nutritional value and nitrate content in edible wild species used in southern Italy. Acta Hortic. 467, 71-90. https://doi.org/10.17660/ ActaHortic.1998.467.7.

Brkić, D., Bošnir, J., Bevardi, M., Bošković, G.A., Miloš, S., Lasić, D., et al. (2017). Nitrate in leafy green vegetables and estimated intake. Afric. J. Trad. Compl. Altern. Med. 14(3). https://doi.org/10.21010/ajtcam.

Cavaiuolo, M., and Ferrante, A. (2014). Nitrates and glucosinolates as strong determinants of the nutritional quality in rocket leafy salads. Nutrients 6(4), 1519-1538. https://doi.org/10.3390/nu6041519.

Chen, X., Guo, W., Xue, X., Wang, L., and Qiao, X. (2014). Growth and quality responses of 'Green Oak Leaf' lettuce as affected by monochromic or mixed radiation provided by fluorescent lamp (FL) and light-emitting diode (LED). Sci. Hortic. 172, 168-175. https:// doi.org/10.1016/j.scienta.2014.04.009.

Chowdhury, A., and Das, A. (2015). Nitrate accumulation and vegetable quality. Int. J. Sci. Res. 4(12). https://doi.org/10.21275/ v4i12.nov152366.

Colla, G., Kim, H., Kyriacou, M.C., and Rouphael, Y. (2018). Nitrate in fruits and vegetables. Sci. Hortic. 237, 221-238. https://doi. org/10.1016/j.scienta.2018.04.016.

Crawford, M.N. (1995). Nitrate: Nutrient and signal for plant growth. Plant Cell 7, 859-868. https://doi.org/10.1105/tpc.7.7.859.

Darko, E., Heydarizadeh, P., Schoefs, B., and Sabzalian, M.R. (2014). Photosynthesis under artificial light: the shift in primary and secondary metabolism. Phil. Transact. Royal Soc. London, Series B, Biol. Sci. 369(1640), 20130243. https://doi.org/10.1098/ rstb.2013.0243.

Deelstra, T., and Girardet, H. (2000). Urban agriculture and sustainable cities. In Growing Cities Growing Food: Urban Agriculture on the Policy Agenda (Thematic Paper 2), p. 43-66.

Dellavalle, C.T., Daniel, C.R., Aschebrook-Kilfoy, B., Hollenbeck, A.R., Cross, A.J., Sinha, R., and Ward, M.H. (2013). Dietary intake of nitrate and nitrite and risk of renal cell carcinoma in the NIH-AARP Diet and Health Study. British J. Cancer 108(1), 205-212. https://doi. org/10.1038/bjc.2012.522.

Di Lorenzo, R., Pisciotta, A., Santamaria, P., and Scariot, V. (2013). From soil to soil-less in horticulture: quality and typicity. Ital. J. Agron. 8(4), 30. https://doi.org/10.4081/ija.2013.e30.

Durazzo, A., Azzini, E., Lazzè, M., Raguzzini, A., Pizzala, R., and Maiani, G. (2013). Italian wild rocket [Diplotaxis tenuifolia (L.) DC.]: Influence of agricultural practices on antioxidant molecules and on cytotoxicity and antiproliferative effects. Agriculture 3(2), 285-298. https://doi.org/10.3390/agriculture3020285.

European Commission (2011). Statement on possible public health risks for infants and young children from the presence of nitrates in leafy vegetables. EFS2 8(12), 98. https://doi.org/10.2903/j. efsa.2010.1935.

European Food Safety Authority (2008). Nitrate in vegetables Scientific opinion of the panel on contaminants in the food chain. EFSA J. 6(6), 689. https://doi.org/10.2903/j.efsa.2008.689.
Fan, XiaoXue, Zang, Jie, Xu, ZhiGang, Guo, ShiRong, Jiao, XueLei, Liu, XiaoYing, and Gao, Ying (2013). Effects of different light quality on growth, chlorophyll concentration and chlorophyll biosynthesis precursors of non-heading Chinese cabbage (Brassica campestris L.). Acta Physiol. Plant. 35(9), 2721-2726. https://doi.org/10.1007/ s11738-013-1304-z.

Folta, K.M., and Maruhnich, S.A. (2007). Green light: A signal to slow down or stop. J. Experim. Bot. 58(12), 3099-3111. https://doi. org/10.1093/jxb/erm130.

Fox, H.R., and Walthall, L.C. (2008). Crop monitoring technologies to assess nitrogen status. Nitrogen in Agric. Syst., Agron. Monograph 49. https://doi.org/10.2134/agronmonogr49.c16.

Fu, Y., Li, H., Yu, J., Cao, Z., and Manukovsky, N.S. (2017). Interaction effects of light intensity and nitrogen concentration on growth, photosynthetic characteristics and quality of lettuce (Lactuca sativa L. var. Youmaicai). Sci. Hortic. 214, 51-57. https://doi.org/10.1016/j. scienta.2016.11.020.

Gangolli, D.S., Van den Brandt, P.A., Feron, V.J., Janzowsky, C., Koeman, H.J., Speijers, J.A.G., et al. (1994). Nitrate, nitrite and N-nitroso compounds. Eur. J. Pharmacol. 292, 1-38. https://doi. org/10.1016/0926-6917(94)90022-1.

Gorenjak, H.A., and Cencič, A. (2013). Nitrate in vegetables and their impact on human health. A review. Acta Alim. 42(2), 158-172. https://doi.org/10.1556/AAlim.42.2013.2.4.

Guadagnin, S.G., Rath, S., and Reyes, F.G.R. (2005). Evaluation of the nitrate content in leaf vegetables produced through different agricultural systems. Food Addit. Contamin. 22(12), 1203-1208. https://doi.org/10.1080/02652030500239649.

Hood-Nowotny, R., Umana, N.H.-N., Inselbacher, E., Oswald-Lachouani, P., and Wanek, W. (2010). Alternative methods for measuring inorganic, organic, and total dissolved nitrogen in soil. Soil Sci. Soc. Am. J. 74(3), 1018. https://doi.org/10.2136/sssaj2009.0389.

Imsande, J., and Touraine, B. (1994). N demand and the regulation of nitrate uptake. Plant Physiol. 105, 3-7.

Johkan, M., Shoji, K., Goto, F., Hahida, S., and Yoshihara, T. (2012). Effect of green light wavelength and intensity on photomorphogenesis and photosynthesis in Lactuca sativa. Environm. Experim. Bot. 75, 128133. https://doi.org/10.1016/j.envexpbot.2011.08.010.

Keszei, A.P., Goldbohm, R.A., Schouten, L.J., Jakszyn, P., and Van den Brandt, P.A. (2013). Dietary N-nitroso compounds, endogenous nitrosation, and the risk of esophageal and gastric cancer subtypes in the Netherlands Cohort Study. Am. J. Clinic. Nutr. 97(1), 135-146. https://doi.org/10.3945/ajcn.112.043885.

Khan, K.A., Yan, Z., and He, D. (2018). Impact of light intensity and nitrogen of nutrient solution on nitrate content in three lettuce cultivars prior to harvest. JAS 10(6), 99. https://doi.org/10.5539/ jas.v10n6p99.

Kim, H.H., Goins, G.D., Wheeler, R.M., and Sager, J.C. (2004a). Greenlight supplementation for enhanced lettuce growth under red- and blue-light-emitting diodes. HortScience 39(7), 1617-1622. https:// doi.org/10.21273/HORTSCI.39.7.1617.

Kim, H.H., Goins, G.D., Wheeler, R.M., and Sager, J.C. (2004b). Stomatal conductance of lettuce grown under or exposed to different light qualities. Ann. Bot. 94(5), 691-697. https://doi.org/10.1093/aob/ mch192.

Kliss, M., Heyenga, A.G., Hoehn, A., and Stodieck, L.S. (2000). Recent advances in technologies required for a "Salad Machine". Adv. Space Res. 26(2), 263-269. https://doi.org/10.1016/S02731177(99)00570-0.

Kmecl, V., Knap, T., and Žnidarčič, D. (2017). Evaluation of the nitrate and nitrite content of vegetables commonly grown in Slovenia. Ital. J. Agron. 12(2), 79-84. https://doi.org/10.4081/ija.2017.801. 
Kozai, T. (2013). Resource use efficiency of closed plant production system with artificial light: Concept, estimation and application to plant factory. Proc. Japan Acad., Series B, Physic. Biol. Sci. 89(10), 447-461. https://doi.org/10.2183/pjab.89.447.

Lillo, C., and Appenroth, K.-J. (2001). Light regulation of nitrate reductase in higher plants: Which photoreceptors are involved? Plant Biol. 3(5), 455-465. https://doi.org/10.1055/s-2001-17732.

Lin, K.H., Huang, M.Y., Huang, W.D., Hsu, M.H., Yang, Z.W., and Yang, C.M. (2013). The effects of red, blue, and white light-emitting diodes on the growth, development, and edible quality of hydroponically grown lettuce (Lactuca sativa L. var. capitata). Sci. Hortic. 150, 8691. https://doi.org/10.1016/j.scienta.2012.10.002.

Liu, H., Fu, Y., and Yu, J. (2016). Accumulation and primary metabolism of nitrate in lettuce (Lactuca sativa L. var. Youmaicai) grown under three different light sources. Commun. Soil Sci. Plant Anal. 47(17), 1994-2002. https://doi.org/10.1080/00103624.201 6.1225076 .

Loconsole, D., Cocetta, G., Santoro, P., and Ferrante, A. (2019). Optimization of LED lighting and quality evaluation of romaine lettuce grown in an innovative indoor cultivation system. Sustainability 11(3), 841. https://doi.org/10.3390/su11030841.

Makino, A., and Osmond, B. (1991). Effects of nitrogen nutrition on nitrogen partitioning between chloroplasts and mitochondria pea and wheat. Plant Physiol. 96, 355-362. https://doi.org/10.1104/ pp.96.2.355.

Miranda, K.M., Espey, M.G., and Wink, D.A. (2001). A rapid, simple spectrophotometric method for simultaneous detection of nitrate and nitrite. Nitric 0xide: Biol. Chem. 5(1), 62-71. https://doi. org/10.1006/niox.2000.0319.

Mitchell, C.A., Both, A., Bourget, M.C., Burr, F.J., Kubota, C., Lopez G.R., et al. (2012). LEDs: The future of greenhouse lighting! Chronica Hortic. 52(1), 6-12.

Molecular Probes (2003). Griess reagent kit for nitrite determination. https://assets.thermofisher.com/TFS-Assets/LSG/manuals / mp07921.pdf.

Morrow, C.R. (2008). LED lighting in horticulture. HortScience 43(7), 1947-1950. https://doi.org/10.21273/HORTSCI.43.7.1947.

$\mathrm{Mu}$, Xiaohuan, Chen, Qinwu, Chen, Fanjun, Yuan, Lixing, and Mi, Guohua (2016). Within-leaf nitrogen allocation in adaptation to low nitrogen supply in maize during grain-filling stage. Front. Plant Sci. 7, 699. https://doi.org/10.3389/fpls.2016.00699.

Oka, Y., Hirayama, I., Yoshikawa, M., Yokoyama, T., Iida, K., Iwakoshi, K., et al. (2016). Survey of nitrate ion concentrations in vegetables cultivated in plant factories: Comparison with open-culture vegetables. https://doi.org/10.3358/shokueishi.58.49.

Olle, M., and Viršile, A. (2013). The effects of light-emitting diode lighting on greenhouse plant growth and quality. AFSci 22(2), 223234. https://doi.org/10.23986/afsci.7897.

Saengtharatip, S., Goto, N., Kozai, T., and Yamori, W. (2020). Green light penetrates inside crisp head lettuce leading to chlorophyll and ascorbic acid content enhancement. Acta Hortic. 1273, 261-270. https://doi.org/10.17660/ActaHortic.2020.1273.35.

Sago, Y., and Shigemura, A. (2018). Quantitative nutrient management reduces nitrate accumulation in hydroponic butterhead lettuces grown under artificial lighting. HortScience 53(7), 963-967. https:// doi.org/10.21273/HORTSCI12418-17.

Santamaria, P. (2006). Nitrate in vegetables: toxicity, content, intake and EC regulation. J. Sci. Food Agric. 86(1), 10-17. https://doi. org/10.1002/jsfa.2351.

Scheible, W.R., Morcuende, R., Czechowski, T., Fritz, C., Osuna, D., Palacios-Rojas, N., et al. (2004). Genome-wide reprogramming of primary and secondary metabolism, protein synthesis, cellular growth processes, and the regulatory infrastructure of Arabidopsis in response to nitrogen. Plant Physiol. 136(1), 2483-2499. https:// doi.org/10.1104/pp.104.047019.

Snowden, M.C., Cope, K.R., and Bugbee, B. (2016). Sensitivity of seven diverse species to blue and green light: interactions with photon flux. PloS ONE 11(10), e0163121. https://doi.org/10.1371/journal. pone.0163121.

Souza, R. de, Peña-Fleitas, M.T., Thompson, R.B., Gallardo, M., Grasso, R., and Padilla, F.M. (2019). The use of chlorophyll meters to assess crop N status and derivation of sufficiency values for sweet pepper. Sensors (Basel, Switzerland) 19(13). https://doi.org/10.3390/ s19132949.

Uddling, J., Gelang-Alfredsson, J., Piikki, K., and Pleijel, H. (2007). Evaluating the relationship between leaf chlorophyll concentration and SPAD-502 chlorophyll meter readings. Photosynth. Res. 91(1), 37-46. https://doi.org/10.1007/s11120-006-9077-5.

United Nations (2017). World population prospects: The 2017 revision. Key findings and advance tables. Working Paper No. ESA/P/ WP/248 (Dept. of Economic and Social Affairs, Population Division).

United Nations (2018). World urbanization prospects: The 2018 revision. Methodology. Working Paper No. ESA/P/WP.252 (Dept. of Economic and Social Affairs, Population Division).

Wanlai, Z., Wenke, L., and Qichang, Y. (2013). Reducing nitrate content in lettuce by pre-harvest continuous light delivered by red and blue light-emitting diodes. J. Plant Nutr. 36(3), 481-490. https:// doi.org/10.1080/01904167.2012.748069.

World Health Organization (2004). Evaluation of ceratin food additives and contaminants. Sixty-first Report of Joint FAO/WHO Expert Committee on Food Additives.

Xiong, D., Chen, J., Yu, T., Gao, W., Ling, X., Li, Y., et al. (2015). SPADbased leaf nitrogen estimation is impacted by environmental factors and crop leaf characteristics. Sci. Rep. 5, 13389. https://doi. org/10.1038/srep13389.

$\mathrm{Xu}, \mathrm{Y}$. (2019). Nature and source of light for plant factory. In Plant Factory Using Artificial Light (Elsevier), p. 47-69. https://doi. org/10.1016/B978-0-12-813973-8.00002-6.

Yosoff, S.F., Mohamed, M.T.M., Parvez, A., Ahmad, S.H., Ghazali, F.M., and Hassan, H. (2015). Production system and harvesting stage influence on nitrate content and quality of butterhead lettuce. Bragantia 74(3), 322-330. https://doi.org/10.1590/1678-4499.0453.

Yuan, L., Yuan, Y., Du, J., Sun, J., and Guo, S. (2012). Effects of 24-epibrassinolide on nitrogen metabolism in cucumber seedlings under $\mathrm{Ca}\left(\mathrm{NO}_{3}\right)_{2}$ stress. Plant Physiol. Biochem. 61, 29-35. https:// doi.org/10.1016/j.plaphy.2012.09.004.

Received: Feb. 11, 2020

Accepted: Jul. 24, 2020

Addresses of authors:

Michael Gräf ${ }^{1, *}$, Rosemarie Stangl ${ }^{1}$, Rebecca Hood-Nowotny ${ }^{2}$ and Andrea Kodym ${ }^{3}$

${ }^{1}$ University of Natural Resources and Life Sciences, Institute of Soil Bioengineering and Landscape Construction, Vienna, Austria

${ }^{2}$ University of Natural Resources and Life Sciences, Institute of Soil Research, Vienna, Austria

${ }^{3}$ University of Vienna, Department of Pharmacognosy,

Vienna, Austria

* Corresponding author; E-mail: Michael.graef@boku.ac.at Tel.: +4369915077760 


\section{SUPPLEMENTAL INFORMATION}

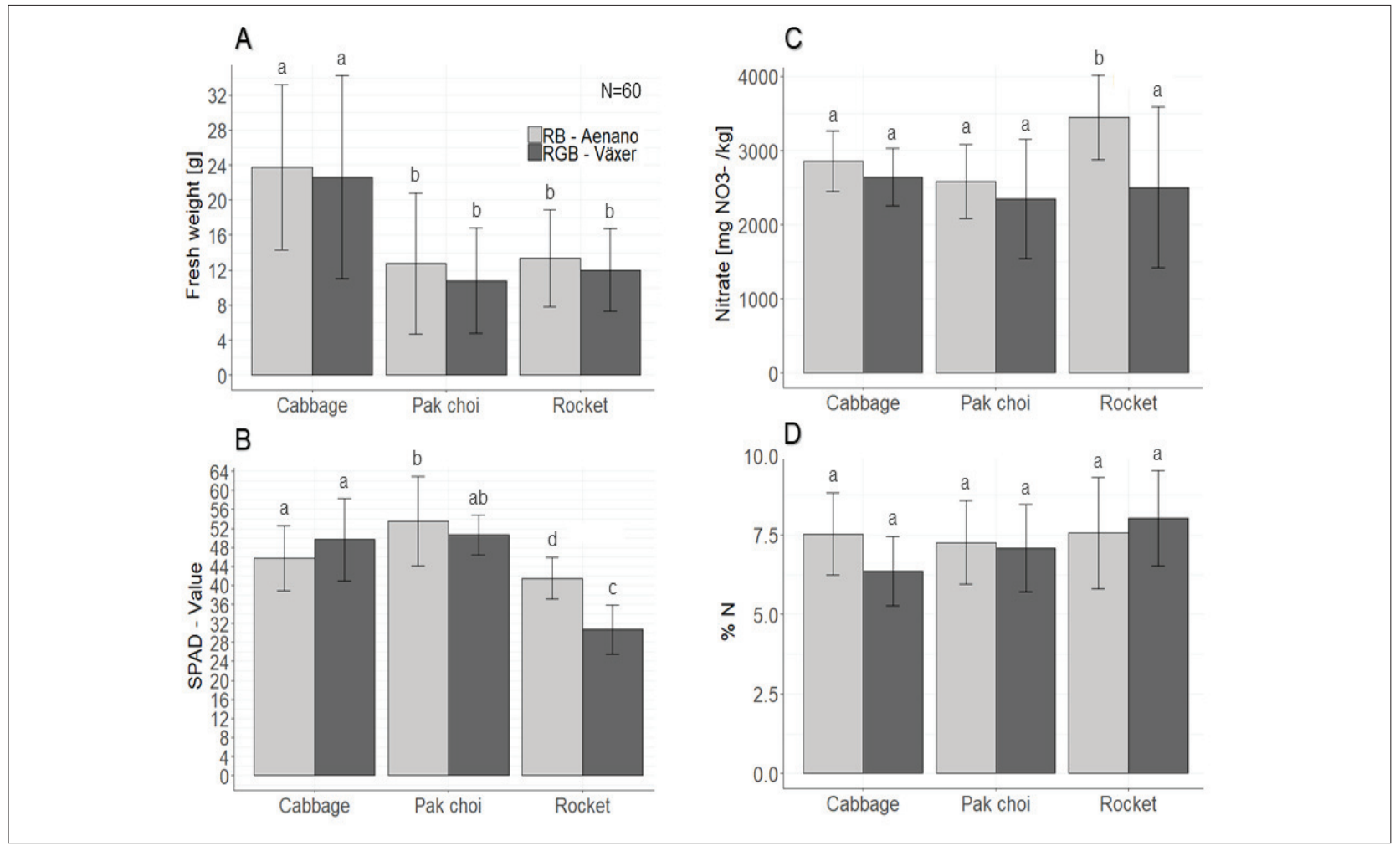

SUPPLEMENTAL INFORMATION - Figure S1. (A) Plant fresh weight, (B) SPAD-value, (C) nitrate content, and (D) percentage N of cabbage, pak choi, and rocket grown under two different light treatments. Vertical bars are means \pm SD. Significant differences $(\mathrm{P}<0.05)$ in each parameter among treatments are indicated by different letters. 
International Workshop on Vertical Farming

13-15 October 2019

Wageningen, The Netherlands

Sponsored by
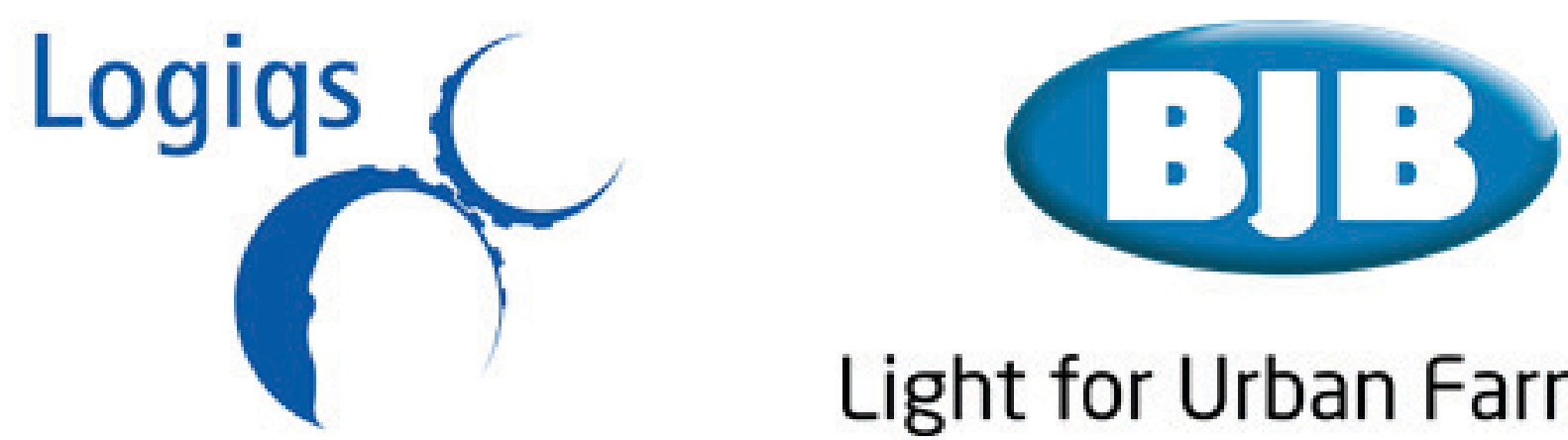

\section{Light for Urban Farming}

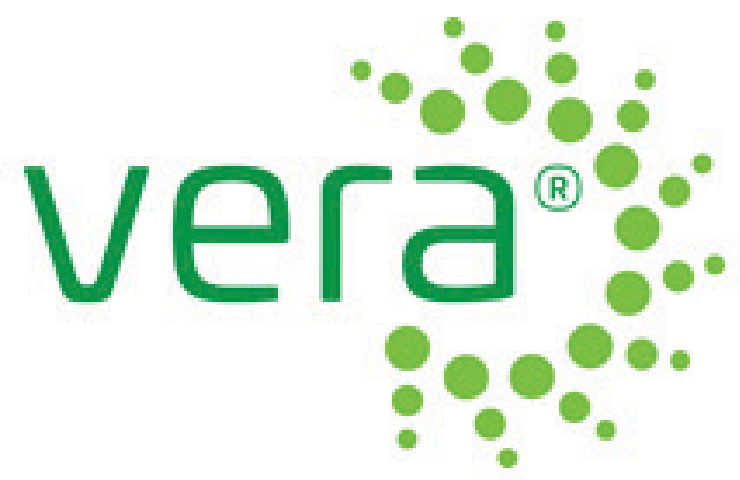

Nouryon

\section{Chelated} Micronutrients
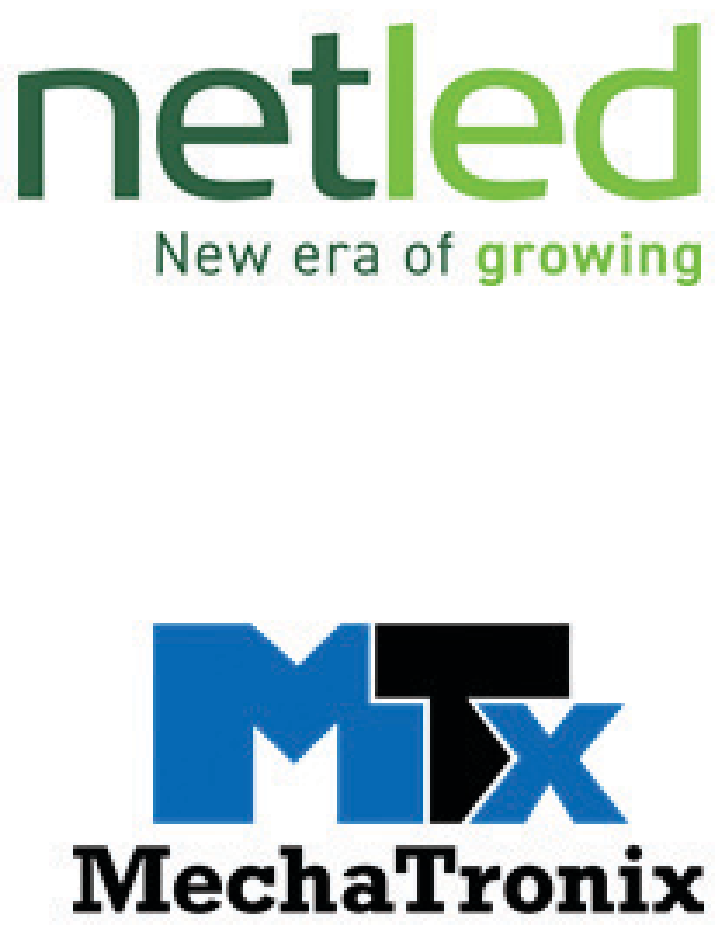

Fடㅁㅁய

$$
\text { F L U E N C E }
$$

